\title{
A Comparative Study of de Certeau and Fiske: Based on the Concepts of "Tactics and Strategies"
}

\author{
Dr. Hüseyin KARAKUŞ \\ karakushus62@gmail.com, Orcid ID: 0000-0003-4043-2935
}

\section{Introduction}

This paper will particularly deal with the practices of cultural consumption based on de Certeau's most notable two concepts: "strategy" and "tactics". Though acknowledging that "consumption is never a passive enterprise", as emphasized by De Certeau in the Practice of Everyday Life; this study will try to oppose to some idealized conception of the everyday consumption;principally focusing on the ideas of John Fiske, in Understanding PopularCulture and Reading the Popular, as one of "the most enthusiastic supporters" of de Certeau, and will try to challenge to the wideknown perception of him "as a theorist of the little victories" by suggesting that "the tactics that de Certeau makes mention arenot libratory in thematerial sense of the word as they do no more than disrupt the fatality of the established order" (Buchanan, 2000: 99). Moreover it is important to note that though de Certeau and Fiske tend to be evaluated within the same "empowerment discourse" in the study of popular culture, what seems to have been underestimated is the very fact that de Certeau's theory of "resistance" differs from the one that is greatly employed by Fiske in the sense that de Certeau's interest is in "subtle movements of escape and evasion" (Buchanan, 2000: 94). In other words, the aim of this study is to emphasize that de Certeau in the Practice of Everyday Life does not offer a study of everyday resistances to the power in the sense Fiske argues; but, draws a picture of how people make their everyday lives.

\section{A Reading on de Certeau}

"In a field overly enamored of the contemporary, de Certeau offers the historian's detailed appraisal of the past. In a field obsessed with the local, de Certeau offers itineraries to elsewhere. In a field where culture tends to be synonymous with the US model, de Certeau points to the other. In a field awash in ordinary, de Certeau grasps the singular. In a field beset with nihilism, de Certeau evokes abiding faith in human history. In a field associated with celebrity stardom, de Certeau provides beguiling self-effacement" (An anonymous reviewer; as cited in Highmore, 2006:xii). 
De Certeau is intellectually an exciting thinker in the sense that he was a man greatly interested in the practices of everyday life, "in what constituted the ordinary" (Ward, 2000:2). Following the "French tradition of concern about "everyday life", that particularly came visible in the work of historians associated with the AnnalesSchool (Dant, 2003:71); de Certeau offered a distinctive way of interpreting the "everyday life" in the societies of the twentieth century, where the consumer capitalism reigned. He was virtually unique amongst other theorists in that he "concentrated mainly on issues of resistance and agency, rather than extant systems of power and dissimulation" (Gardiner, 2000:168). However, he was also the one whose theories, particularly that of "strategies and tactics"; were, and still are, the most poorly interpreted (Buchanan, 2000:86), as will be discussed in the following parts of the study.

De Certeau's focus, as one of the least pessimistic thinkers, on the "everyday life" wasunusual, particularly when compared to the theorists of Frankfurt School for whom "everyday life under modernity was thoroughly routinized and degraded" (Gardiner, 2000:158). In the Dialectic of Enlightenment, Adorno with Horkheimer emphasized that the everyday life underthe dominance of culture industries; which led not only to the commodification and standardization of cultural forms, but also to "the standardization and automatization of responses", served particularly well to weaken the individual resistance to the dominant ideology of capitalism (Gardiner, 2000:160). In a field,where the role of the individual was confined to "moving about, working, eating, and sleeping in a series of technocratically constructed and utilitarian spaces within which nothing was left to chance" (Gardiner, 2000:170), de Certeau said something revolutionary: "People walk their own way through the grid of city streets. People read in ways that escape the social hierarchy and 'imposed system' of written texts" (as cited in Davis, 2008).

De Certeau, referring to Foucault's analysis of "discipline" in Discipline and Punish, commented that (1984: xiv):

"If it is true that the grid of "discipline" is everywhere becoming clearer and more extensive, it is all the more urgent to discover how an entire society resists being reduced to it, what popular procedures...manipulate the mechanisms of discipline and conform to them only in order to evade them, and finally what 'ways of operating' form the counterpart, on the consumer's... side, of the mute processes that organize the establishment of socioeconomic order".

Though he acknowledged the very fact that "the individuals were caught up in the nets of discipline" (1984: xiv), de Certeau wanted to understand anti-disciplines, "the silent and unacknowledged forms of resistance" (Gardiner, 2000:168), particularly detected in the activities of everyday consumption.

"De Certeau was critical of the impact of consumer society" but, unlike the 
Frankfurt theorists' view of the individual; that is he/she was "assumed to be passive and guided by the established rule", he "investigated the ways through which individuals manage to maintain some control of their everyday lives" (Dant, 2003:75).In the Practice of Everyday Life, de Certeau argued that "consumption is never a passive enterprise; rather it is another form of production as it involves consumer's art of using and making-do with objects". He emphasized that the role of the individual was not solely confined to consuming, but "producing" as well. However this sort of production that de Certeau mentioned was different from the capitalist modes of production in the sense that it did "not manifest itself in products as such but, rather through its ways of using the products imposed by a dominant order" (as cited in Buchanan, 2000:83); as, for instance, exemplified in indigenous Indians' confrontation to the Spanish colonizers (1984: xiii):

"Submissive, and even consenting to their subjection, the Indians nevertheless often made of the rituals, representations, and laws imposed on them something quite different from what their conquerors had in mind; they subverted them not by rejecting or altering them but by using them with respect to ends and references foreign to the system they had no choice but to accept... They escaped it without leaving it. The strength of their difference lay in procedures of consumption".

In contrast to the theorists of Frankfurt School, de Certeau emphasized that the popularmasses are not victims of "false-consciousness" as they do not simply internalize the values and beliefs supplied to them" (Gardiner, 2000:171), as detected in the everyday activities of consumption that were "tactical" in character.

\section{On the Concepts of "Strategy" and "Tactics"}

De Certeau makes it clear that consumer capitalism is certainly oppressive and domineering. However, he also points out, "ultimately it cannot fully contain the spontaneous and imaginative energies of the individual" (as cited in Gardiner, 2000:164) operating in a regular daily routine. "Talking, reading, dwelling, shopping, cooking, etc" - all these are spheres in which the individual creativity makes itself visible.

As Ahearne points out (as cited in Gardiner, 2000:168) “de Certeau's work on everyday life resolves primarily around the distinction between 'tactics' and "strategies"'. According to de Certeau, "strategy is a technique of place, and tactics is a technique of space" (as cited in Buchanan, 2000:89); that is "the powerful construct 'places' where they can exercise their power-cities, shopping malls, schools, workplaces, and houses whereas the weak make their own spaces within those places by making the places temporarily theirs as they move through them, occupying them for as long as they need or have to" (Fiske,1989:32).In other words, "the place of a tactic belongs to the other". Tactics are the characteristic of everyday practice that "insinuates itself into the other's place silently and almost 
invisibly" since being without a place, tactics are dependent on time, watching for opportunities and manipulating events" (de Certeau, as cited in Dant, 2003:79). Tactics, "as the arts of the weak" (de Certeau: 1984:37), are opportunistic and spontaneous; and employed when an individual "does not possess strong resources for resistance or autonomy". Strategies, on the other hand, sharply contrasting with tactics, are determined with the presence of a proper place intended to serve as a "'homebase' for the exercise of power and domination" (de Certeau, as cited in Gardiner, 2000:172). Buchanan emphasizes that "strategy works to limit sheer number of variables affecting us by creating some kind of protected zone, a place in which the environment can be rendered predictable if not properly tamed" whereas tactics "is the approach one takes to everyday life when one is unable to take measures against its variables" (2000: 89). In other words, tactics, referring to the practices that strategy has not been able to tame, make themselves visible in lack of authority.

\section{A Reading on de Certeau from the Eyes of Fiske}

John Fiske in Understanding the Popular (1989b:193) suggests that what he attempts to do is to outline a theory of popular culture that "is both positive and optimistic". Applying the theories of de Certeau, Barthes, Hall, and Bakhtin, "that are European in origin", to the popular culture of the United States; Fiske gives a reading of popular culture products, ranging from "shopping malls to Madonna, from beaches to jeans" (1989b:x).

Fiske, seeing "popular culture as a site of struggle", concentrates on the popular tactics by which the dominant forces are coped with, evaded or resisted(1989b:20). According to Fiske, who particularly employs the theories of de Certeau; popular culture, "baring the traces of the constant struggle between domination and subordination", assumes the potential fora "social change" (1989b:19), in which "the tactics of everyday life" are to play a vital role. However what seems to have escaped from Fiske, as one of the most enthusiastic supporters of de Certeau's theories, particularly that of "tactics and strategies", is the very fact that "de Certeau'sinterest is not in the production of difference, but in the different productions", as Buchanan puts into words (2000:94).

According to Fiske "everyday life is constituted by the practices of popular culture, and is characterized by the creativity of the weak in using the resources provided by a disempowering system while refusing to submit to that power" (1989b:47), as popularized in the theory of "excorporation". Excorporation, as he puts forward (1989b:15)refers to "the process by which the subordinate make their own culture out of the resources and commodities provided by the dominant system". He argues that the study of "popular culture requires the study not only of the cultural commodities out of which it is made, but also the ways that people use them" (1989b:15), reproducing the theories of de Certeau who advocates that "what is counted is the ways of using not what is used" (1984:35). Though Fiske never denies 
that his analysis of the popular culture mostly is based on the theories of de Certeau, what is disturbing about Fiske's analysis is his overwhelming optimism of consumer capitalism and his celebration of the popular culture for its "empowering" quality as, for instance, detected in his example of "torn-jeans". Fiske suggests that "wearing torn jeans is anexample of the contradictions that are so typical of popular culture, where what is to be resisted is necessarily present in the resistance to it" (1989b:4).

"Torn-jeans" are not the only examples used by Fiske to explain the theory of "excorporation". For instance; according to Fiske, Madonna, as a popular icon, serves to the "feminine resistance" in the sense that "her image is a site of semiotic struggle between the forces of patriarchal control and feminine resistance, of capitalism and the subordinate, of the adult and the young" (1989a: 87). Fiske asserts that while Madonna's performance could easily be read as a celebration of sexist patriarchal male pleasures, some girls in the audience may "excorporate" the message that Madonna "celebrates females taking charge of their own sexuality in a liberating way". Even the excess in her appearance, according to Fiske; that is "excesses of jewelry, of make-up, of trash in her style", invite the viewer "to question ideology and offers scope for resistance" (1989a:105).

De Certeau's (1984) depiction of "consumer-as-trickster" has also been employed by Fiske.According to Fiske, "shopping mall as the terrain of "guerilla warfare" is where the "art and tricks of the weak" can cause most damage on (1989a:14). For instance, Fiske too optimistically interprets an apron bearing the slogan "Woman's place is in the mall" as women's subversion of patriarchy; taking this interpretation further, he compares shopping women with guerrillas for the way "they resist marginalization by spending their husbands" money" (1989a:15). Moreover Fiske asserts that "buying commodities offers a sense of freedom and subversion of dominant ideologies; therefore, consumption should be celebrated for its empowering quality" (as cited in Bilgin, 2010:310).

Considering all the assumptions discussed above, regarding the study of everyday life, it is without doubt that Fiske celebrates popular culture, under the dominance of consumer capitalism, for its "empowering quality". However, the disturbing facts lies in his study of popular culture; as, for instance, detected in his "interpretation ofany ways of operating or consumers' meaning-making labor as subversion", as suggested by Bilgin, (2010:310). As Bilgin (2010: 310) emphasizes "one may questionwhether the apron example Fiske uses can still be considered a sign of subversion ifthe slogan has been conceived by a male designer or if the apron is a gift from a man". Though the same criticism can also be applied to de Certeau; that is he "seems to underestimate the extent that acts of consuming are socially structuredand bound by social relations as well as institutions" (Bilgin, 2010:311); de Certeau never speaks of consumerism in a celebratory way; nor gives an emphasis on its "empowering quality" as he is "not relying on a conception of the perfectly rational, autonomous subject" (Gardiner, 2000:173). Though, for de Certeau, the consumer is 
never characterized as being "passive, dupe, spectator or slave" (Bilgin, 2010: 307); he/she is never assumed to be "the master". In this sense, consumers, though trapped in a dominating and manipulative system, are "poachers", armed with "clever tricks, knowing how to get away with things, hunter's cunning" (de Certeau, 1984: xix).

"Resistance", on the other hand, is another concept that seems to have been poorly understood by Fiske. De Certeau's use of "resistance" should be evaluated within the material sense of the word; that is "resistance" in de Certeau, refers to the movements of "escape" and "evasion". However, Fiske makes use of the word in such a way that "resistance" refers to the altering of the dominant, as, for instance, exemplified in his view on feminist movement suggesting that "individual women, in their lives, constantly make 'guerrilla raids' upon patriarchy, win small, fleeting victories. And gradually, reluctantly, patriarchy has to change in response" (1989b:20). De Certeau's resistance, on the other hand, does not aim at structural changes on the system; but rather an "escape" from it.

\section{Conclusion}

Within a pessimistic picture of the consumer and the modern society in the field of cultural studies, de Certeau evokedoptimismin the sense that he offered "the possibility of theorizing everyday life" (Buchanan, 2000b:94).In contrast to the depiction of the consumer as a mindless, passive creature, thoroughly pacified by the ideology of consumerism; de Certeau talked about the "cunningness" of people. In a field where it was already asserted that"conformity" has replaced "consciousness"; de Certeau advocated that everyday life was full of activities that might resist to the pressure to conform.

However, as he became increasingly recognized within the field, and his theories became more appealing to other cultural theorists; he faced with the potential of misinterpretation. As discussed in this study, within the theories of de Certeau "tactics and strategies" are the most recognized; but also poorly understood and idealized ones, as already discussed in Fiske's analysis of popular culture. It is without doubt that "de Certeau's arguments regarding the nature of consumption challenged a range of orthodoxies" (Gardiner, 2000:179). However, though he seems to "overemphasize the resistant qualities of everyday consumption"(Gardiner, 2000:179), it would be inconvenient to suggest that de Certeau attributes "utopian" qualities to popular consumption, as in the case of Fiske.

\section{References}

Bilgin, E. (2010). "An interdisciplinary review of resistance to consumption, some marketing interpretations, and future research suggestions" in Consumption Markets \& Culture, Vol.13, No.3, p. 299-323. 
Retrievedfrom http://docs.business.auckland.ac.nz/Doc/Review-of-resistance-toconsumption-marketing -interpretations-future-research-suggestions.pdf.

Buchanan, I. (2000). Introduction to "Other People: Ethnography and Social Practice" in theCerteau Reader (eds. Ward, G.), Oxford: Blackwell Publishers, p. 97-101.

Buchanan, I. (2000) "Tactics and Strategies" in Michel De Certeau: Cultural Theorist, London: Sage Publications, p. 86-108.

Dant, T. (2003). "The Critique in Everyday Life" in Critical Social Theory, London: Sage Publications, p. 65-85.

De Certeau, M. (1984). The Practice of Everyday Life, Berkeley: University of, Volume 1, California: CaliforniaPress.

Fiske, J. (1989a). Reading the Popular, New York: Routledge.

(1989b). Understanding Popular Culture, New York: Unwin Hyman, p. 1-49.

Gardiner, M. (2000). "Michel de Certeau: the cunning of unreason" in the Critique of Everyday Life, New York: Routledge, p. 157-180.

Highmore, B. (2006). Preface and Acknowledgements in Michel de Certeau: Analysing Culture, New York:Continuum International Publishing Group, p. ix-1. 